This is the peer reviewed version of the following article: Gamba, I., Salvadó, I., Rama, G., Bertazzon, M., Sánchez, M. I., Sánchez-Pedregal, V. M., Martínez-Costas, J. , Brissos, R. F., Gamez, P., Mascareñas, J. L., Vázquez López, M. and Vázquez, M. E. (2013), Custom-Fit Ruthenium(II) Metallopeptides: A New Twist to DNA Binding With Coordination Compounds. Chem. Eur. J., 19: 13369-13375, which has been published in final form at https://doi.org/10.1002/chem.201301629.

This article may be used for non-commercial purposes in accordance with Wiley Terms and Conditions for Use of Self-Archived Versions 


\title{
Custom-fit ruthenium(II) metallopeptides: A new twist to DNA binding with coordination compounds
}

\author{
Ilaria Gamba, ${ }^{[b], \Delta}$ Iria Salvadó, ${ }^{[a], \Delta}$ Gustavo Rama, ${ }^{[b], \Delta}$ Miriam Bertazzon, ${ }^{[a]}$ Mateo I. Sánchez, ${ }^{[a]}$ \\ Víctor M. Sánchez-Pedregal, ${ }^{[\mathrm{a}]}$ José Martínez-Costas, ${ }^{[\mathrm{cc}]}$ Rosa F. Brissos, ${ }^{[\mathrm{d}]}$ Patrick Gamez, ${ }^{[\mathrm{d}]}$ José L. \\ Mascareñas, ${ }^{[a]}$ Miguel Vázquez López ${ }^{[b], *}$ and M. Eugenio Vázquez ${ }^{[a], *}$
}

\begin{abstract}
A new bipyridine building block has been used for the solid-phase synthesis of dinuclear DNA-binding ruthenium(II) metallopeptides. Detailed spectroscopic studies suggest that these compounds bind to the DNA by insertion into the DNA minor groove.
\end{abstract}

Moreover, the potential of the solidphase peptide synthesis approach is demonstrated by the straightforward synthesis of an octaarginine derivative that shows effective cellular internalization and cytotoxicity linked with strong DNA interaction, as evidenced by steady-state fluorescence spectroscopy and AFM studies.

Keywords: molecular recognition •
DNA recognition $\bullet$ fluorescence $\bullet$
metallopeptides $\bullet$ supramolecular
chemistry

\section{Introduction}

Mapping the human genome has provided a wealth of information and potential DNA targets of both therapeutic and diagnostic

[a] I. Salvadó, M. Bertazzon, M. I. Sánchez, Prof. V. Sánchez-Pedregal, Prof. José L. Mascareñas, Prof. M. Eugenio Vázquez*

Departamento de Química Orgánica, Centro Singular de Investigación en Química Biolóxica e Materiais Moleculares and Unidad Asociada al CSIC, Universidade de Santiago de Compostela, 15782 Santiago de Compostela (Spain)

E-mail: eugenio.vazquez@usc.es

[b] Dr. I. Gamba, G. Rama, Prof. M. Vázquez López* Departamento de Química Inorgánica y Centro Singular de Investigación en Química Biolóxica e Materiais Moleculares, Universidade de Santiago de Compostela, 15782 Santiago de Compostela (Spain)

E-mail: miguel.vazquez.lopez@usc.es

[c] Prof. J. Martínez-Costas

Departamento de Bioquímica y Centro Singular de Investigación en Química Biolóxica e Materiais Moleculares, Universidade de Santiago de Compostela, 15782 Santiago de Compostela (Spain)

[d] R. F. Brissos, Prof. Patrick Gamez

Departament de Química Inorgànica, QBI, Universitat de Barcelona, 08028, Barcelona (Spain) and Institució Catalana de Recerca i Estudis Avançats (ICREA), 08010 Barcelona (Spain)

$\Delta$, these authors contributed equally.

Supporting information for this article is available on the WWW under http://www.chemeurj.org/ or from the author. relevance that has stimulated the search for new DNA binding agents. ${ }^{1}$ In addition to the extensive development of small organic binders, the past few years have witnessed an increased interest on the application of coordination compounds as DNA-targeted probes, reactive agents and therapeutics. ${ }^{2,3,4}$ Among them, ruthenium(II) polypyridyl mononuclear complexes have been exhaustively studied for their kinetic stability and convenient redox and optical properties. ${ }^{5,6,7}$ Surprisingly, dinuclear ruthenium (II) derivatives, despite systematically displaying better DNA-binding properties than their mononuclear counterparts, ${ }^{8}$ have scarcely been studied to date, ${ }^{9}, 10,11,12$ hampered by the stiff synthetic methodologies commonly used in the assembly of polypyridyl chelators that severely limit the structural modifications that can be efficiently accessed. ${ }^{13}$ Given our experience in the study of DNA recognition agents, particularly minor groove binders, ${ }^{14}$ and metallopeptides, ${ }^{15}$ we sought to fill this gap with the development of custom-fit dinuclear ruthenium (II) metallopeptides, which could potentially combine the unique photophysical properties of the $\mathrm{Ru}(\mathrm{II})$ polypyridyl complexes with the synthetic versatility of solid-phase peptide synthesis methods that would allow the straightforward modification of the bis-chelating ligand for the modulation of the biophysical properties of the resulting complexes. ${ }^{16}$ To this end, we reasoned that appropriate derivatization of the widely used 2,2'bipyridine chelator in the form of a Fmoc-protected amino acid, might allow the straightforward solid-phase synthesis of metallopeptide precursor ligands, which could be easily tweaked in order to efficiently optimize the DNA-binding and biological properties of their resulting ruthenium(II) metallopeptides. 


\section{Results and Discussion}

Metallopeptide design and synthesis. Based on previous reports studying related bipyridine amino acids, ${ }^{17}$ we chose the Fmoc- $\beta$ AlaBpy-OH dipeptide (1, Scheme 1) as the basic building block of our bis-chelating peptidic ligands. Following the synthesis of 1 using known procedures (supplementary information) ${ }^{15}$ we designed two simple peptide ligands containing two $\beta$ Ala-Bpy coordinating units in tandem (Ac- $\beta$ Ala-Bpy- $\beta$ Ala-Bpy- $-\mathrm{NH}_{2}$ ), or separated by a short glycine residue linker (Ac- $\beta$ Ala-Bpy-Gly- $\beta$ Ala-Bpy- $\mathrm{NH}_{2}$ ), as simple test cases to demonstrate the flexibility of the SPPS methodology for the straightforward structural variation of the peptidic ligands. The peptides were synthesized following standard Fmoc/tBu solid-phase protocols..$^{18}$ Once fully assembled - and while still attached to the solid support - the peptides were coordinated with the enantiopure Hua and von Zelewsky's $\Lambda$-cis$\left[\mathrm{Ru}(\mathrm{Bpy})_{2}(\mathrm{py})_{2}\right]^{2+}$, or $\Delta$-cis-[Ru(Bpy $\left.)_{2}(\mathrm{py})_{2}\right]^{2+}$ reagents, ${ }^{19}$ to give the desired $\mathbf{\Lambda} \mathbf{\Lambda}-$ or $\mathbf{\Delta} \mathbf{\Delta}-\mathbf{R} \mathbf{u}_{2}$ and $\mathbf{\Lambda} \mathbf{\Lambda}-$ or $\mathbf{\Delta} \mathbf{\Delta}-\mathbf{R} \mathbf{u}_{\mathbf{2}} \mathbf{G l y}$ dinuclear complexes attached to the solid support (Scheme 1). Acidic cleavage, followed by reverse-phase HPLC purification, afforded the desired $\mathrm{Ru}$ (II) metallopeptides. It should be highlighted that the formation of the complexes in the solid phase from bis-bipyridine $\mathrm{Ru}(\mathrm{II})$ reagents outperforms widely used solution procedures,${ }^{20}$ allowing the use of greater excess of metal precursors and simplifying the subsequent purification steps. ${ }^{21}$ To our knowledge, these species represent the first reported examples of dinuclear $\mathrm{Ru}(\mathrm{II})$ metallopeptides. ${ }^{22}$
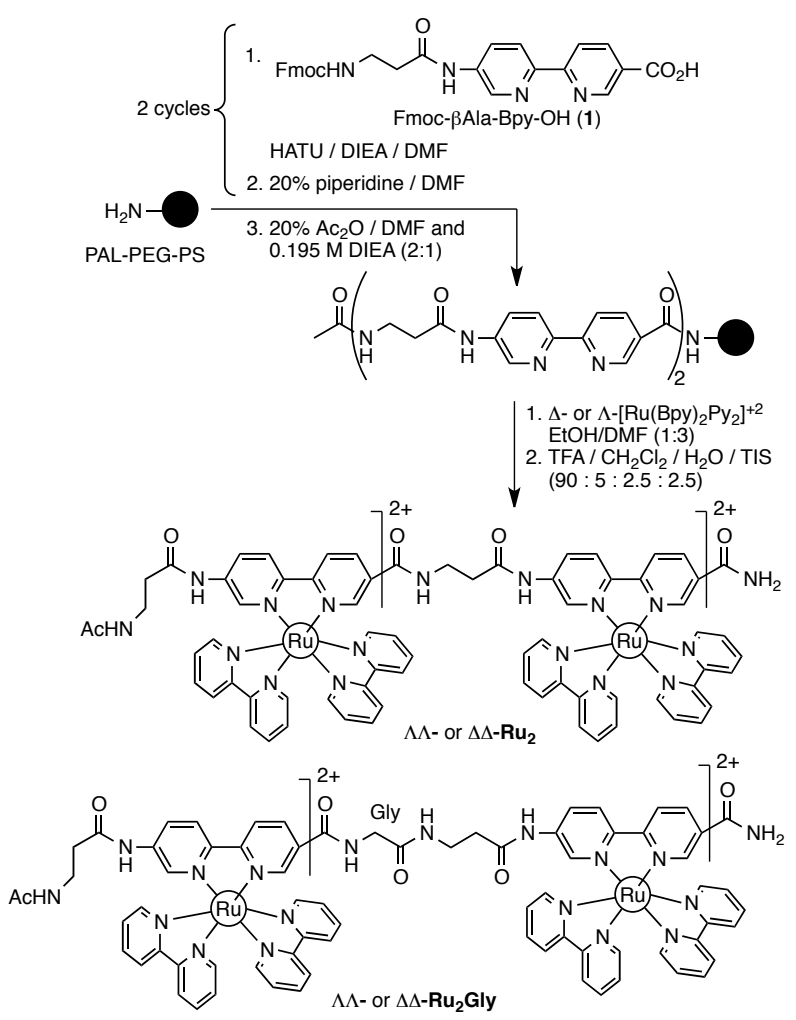

Scheme 1. Solid-Phase Peptide Synthesis of the model $\mathbf{\Lambda} \mathbf{\Lambda}-$ and $\mathbf{\Delta} \boldsymbol{\Delta}-\mathbf{R} \mathbf{u}_{2}$ dinuclear complexes. $\mathbf{\Lambda} \mathbf{\Lambda}-$ and $\mathbf{\Delta} \mathbf{\Delta}-\mathbf{R} \mathbf{u}_{2} \mathbf{G l y}$ are synthesized following the same procedure.

DNA binding studies. The basic DNA binding properties of the $\mathbf{\Lambda} \mathbf{\Lambda}-$ and $\mathbf{\Delta} \mathbf{\Delta}-\mathbf{R} \mathbf{u}_{2}$ dinuclear complexes were initially assessed by displacement experiments with ethidium bromide. ${ }^{23}$ Additionally, emission-quenching experiments showed that both $\mathbf{\Lambda} \mathbf{\Lambda}-$ and $\mathbf{\Delta} \boldsymbol{\Delta}-$
$\mathbf{R} \mathbf{u}_{2}$ were effectively protected from luminescence deactivation with $\left[\mathrm{Fe}(\mathrm{CN})_{6}\right]^{4-}$ in the presence of calf thymus DNA (ctDNA). ${ }^{24}$ Thus, the ratio of the slopes in the absence and in presence of ctDNA, which is used as a measure of the protection of DNA-bound complexes against the dynamic quenching by the $\left[\mathrm{Fe}(\mathrm{CN})_{6}\right]^{4}$, resulting from electrostatic repulsion of the highly anionic ferricyanide from the polyanionic DNA, is 12.1 for $\mathbf{\Lambda} \mathbf{\Lambda}-\mathbf{R} \mathbf{u}_{2}$ and 7.3 for $\Delta \mathbf{\Delta}-\mathbf{R} \mathbf{u}_{2}$. These values are in the same range of those observed for other $\mathrm{Ru}$ (II) complexes that interact with the DNA (Supporting information, Figure S2). These preliminary experiments showed that, in contrast to the mononuclear tris-bipyridyl complex, ${ }^{25}$ both $\mathbf{\Lambda} \mathbf{\Lambda}-$ and $\boldsymbol{\Delta} \boldsymbol{\Delta}-\mathbf{R} \mathbf{u}_{2}$ display significant DNA binding affinities (see supporting information, Figure S1). Encouraged by these results, we decided to exploit the intrinsic emission of the $\mathrm{Ru}(\mathrm{II})$ metallopeptides and their environment-sensitive luminescence for studying their interaction with synthetic oligonucleotides, ${ }^{26}$ which would allow us to obtain quantitative information about their binding affinity towards particular DNA sequences. Thus, addition of successive aliquots of a stock oligonucleotide solution to $1 \mu \mathrm{M}$ solutions of $\mathbf{\Lambda} \mathbf{\Lambda}-$ or $\mathbf{\Delta} \mathbf{\Delta}-\mathbf{R} \mathbf{u}_{2}$ in Tris- $\mathrm{HCl}$ buffer resulted in a progressive increase in the emission intensity of the $\mathrm{Ru}(\mathrm{II})$ complexes, which was fitted to a binding model corresponding to the formation of specific $\mathbf{\Lambda} \mathbf{\Lambda}-$ and $\boldsymbol{\Delta} \boldsymbol{\Delta}-\mathbf{R} \mathbf{u}_{2} /$ dsDNA complexes (Figure 1).
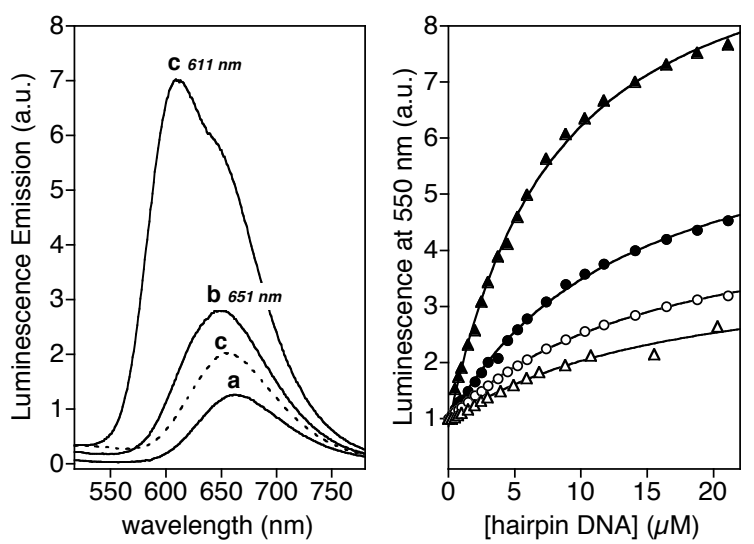

Figure 1. Left: (a) Luminescence spectra of $1 \mu \mathrm{M}$ solutions of $\mathbf{\Lambda} \mathbf{\Lambda}-\mathbf{R} \mathbf{u}_{2}$ or $\mathbf{\Delta} \mathbf{\Delta}-\mathbf{R} \mathbf{u}_{2}$ in $20 \mathrm{mM}$ Tris-HCl buffer, $100 \mathrm{mM} \mathrm{NaCl}, \mathrm{pH} 7.5$; (b) $\mathbf{\Lambda} \mathbf{\Lambda}-\mathbf{R u}_{2}$ in the presence of $20 \mu \mathrm{M}$ of the GGCC hairpin oligonucleotide; (c, solid line) $\mathbf{\Lambda} \mathbf{\Lambda}-\mathbf{R} \mathbf{u}_{2}$ in the presence of $21 \mu \mathrm{M}$ of the AAAATTT hairpin oligo; (c, dashed line) $\mathbf{\Delta \Delta}-\mathbf{R} \mathbf{u}_{2}$ in the presence of $21 \mu \mathrm{M}$ of the AAAATTT hairpin oligo. Right: Titration profiles of $1 \mu \mathrm{M} \Lambda \mathbf{\Lambda}-\mathbf{R} \mathbf{u}_{2}$ with AAAATTT $(\triangle)$; AAT $(\bullet)$; AAGCTT $(\circ)$, and GGCC $(\Delta)$ oligonucleotides. Lines represent the best fit to a 1:1 binding model. Hairpin DNA oligonucleotide sequences, AAAATTT: 5'-GGC AAAATTT CGTTTTTCG AAATTTT GCC -3'; AAT: 5'-GGCG AAT GCAGCTTTTTGCTGC $A T T$ CGCC -3'; AAGCTT: 5'- GGC AAGCTT CGCTTTTTGCG AAGCTT GCC -3'; GGCC: 5'- GGCAGGCCCAGC TTTTT GCTGGGCCTGCC -3 '.

The resulting apparent dissociation constants were strongly dependent on the oligonucleotide sequences, so that the lower apparent dissociation constants - as well as larger increases in the emission intensity - were observed for the A/T-rich oligonucleotides, while G/C-containing oligos only induced a modest increase in emission intensity and showed weaker apparent binding (Table 1). Moreover, $\mathbf{\Lambda} \mathbf{\Lambda}-\mathbf{R} \mathbf{u}_{2}$ consistently displayed stronger DNA binding affinities than its enantiomeric $\mathbf{\Delta} \boldsymbol{\Delta}-\mathbf{R} \mathbf{u}_{2}$ counterpart; this preferential DNA binding of the $\mathbf{\Lambda} \mathbf{\Lambda}$ - enantiomer is consistent with earlier reports of chiral discrimination in homochiral dinuclear $\mathrm{Ru}(\mathrm{II})$ complexes, for which a preference of the $\mathbf{\Lambda} \mathbf{\Lambda}$-isomers for DNA 
binding was also observed. ${ }^{27}$ In addition to the increased DNA affinity observed for the $\mathbf{\Lambda} \mathbf{\Lambda}-\mathbf{R} \mathbf{u}_{\mathbf{2}}$ metallopeptide, its luminescence intensity in the presence of a high-affinity binding sequence (AAATTT) was much higher than that of the $\mathbf{\Delta} \boldsymbol{\Delta}-\mathbf{R} \mathbf{u}_{\mathbf{2}}$ complex (Figure 1c, solid and dashed lines, respectively), and centered at a much shorter emission wavelength, hence suggesting a larger change in its immediate environment upon binding. This observation, together with the binding preference for A/T-rich sequences, would be consistent with a deeper insertion mechanism of this complex into the DNA minor groove.

Titrations with the $\mathbf{\Lambda} \mathbf{\Lambda}-$ and $\mathbf{\Delta} \mathbf{\Delta}-\mathbf{R} \mathbf{u}_{\mathbf{2}} \mathbf{G l y}$ dinuclear metallopeptides showed similar tendencies to those of their homologous complexes lacking the Gly linker. Thus, the $\mathbf{\Lambda} \mathbf{\Lambda}-\mathbf{R} \mathbf{u}_{\mathbf{2}} \mathbf{G l y}$ isomer displayed better apparent binding constants than $\mathbf{\Delta} \mathbf{\Delta}-\mathbf{R} \mathbf{u}_{\mathbf{2}} \mathbf{G l y}$, and both showed a clear preference for binding to extended A/T-rich oligonucleotides. Curiously, the glycine linker had subtle effects on the binding of these dinuclear metallopeptides, and while it had a slightly negative effect on the DNA binding of the $\mathbf{\Lambda} \mathbf{\Lambda}-\mathbf{R} \mathbf{u}_{\mathbf{2}} \mathbf{G l y}$ isomer compared to the model $\mathbf{\Lambda} \mathbf{\Lambda}-\mathbf{R} \mathbf{u}_{2}\left(K_{D}\right.$ [AAATTT] $\approx 8.2$ and $5.8 \mu \mathrm{M}$, respectively), it induced an opposite, slightly favorable effect, on the DNA binding of the $\mathbf{\Delta} \boldsymbol{\Delta}-\mathbf{R} \mathbf{u}_{\mathbf{2}} \mathbf{G l y}$ stereoisomer in comparison with the $\boldsymbol{\Delta} \mathbf{\Delta}-\mathbf{R} \mathbf{u}_{\mathbf{2}}$ model compound $\left(K_{D}\right.$ [AAATTT] $\approx 31$ and $14 \mu \mathrm{M}$, respectively), which again suggests some differences in the DNA binding modes of the isomeric complexes. As expected, no measurable binding was detected in control experiments with singlestranded DNA oligonucleotides. Circular Dichroism experiments show an induced $\mathrm{CD}$ band at $320 \mathrm{~nm}$ by the $\mathbf{\Lambda} \mathbf{\Lambda}-\mathbf{R} \mathbf{u}_{\mathbf{2}}$ isomer (supporting information, Figure S4a), which has been also reported for other $\mathrm{Ru}$ (II) complexes, ${ }^{28}$ but more importantly they show that the shape of the CD signals between 200 and $300 \mathrm{~nm}$, corresponding to the DNA, are not significantly perturbed, thus indicating the retention of the B-DNA conformation. ${ }^{29}$

Table 1. Dissociation constants of dinuclear $\mathbf{\Lambda} \mathbf{\Lambda}_{-}, \mathbf{\Delta} \mathbf{\Delta}-\mathbf{R} \mathbf{u}_{2}$ and $\mathbf{\Lambda} \mathbf{\Lambda}_{-}, \boldsymbol{\Delta} \mathbf{\Delta}-\mathbf{R} \mathbf{u}_{2} \mathbf{G l y}$ with selected oligonucleotides.

\begin{tabular}{lllll}
\hline Oligo $^{[\mathrm{a}]}$ & $\boldsymbol{\Delta} \boldsymbol{\Delta}-\mathbf{R u}_{2}{ }^{[\mathrm{b}]}$ & $\boldsymbol{\Lambda \Lambda}-\mathbf{R u _ { 2 }}$ & $\boldsymbol{\Delta} \boldsymbol{\Delta}-\mathbf{R u _ { 2 }} \mathbf{G l y}$ & $\boldsymbol{\Lambda \Lambda}-\mathbf{R u}_{2} \mathbf{G l y}$ \\
\hline AAAATTT & $31.0(7.0)$ & $5.8(0.7)$ & $13.9(2.5)$ & $8.2(1.8)$ \\
AAT & $24.5(3.5)$ & $12.0(0.6)$ & $15.2(2.6)$ & $11.6(1.6)$ \\
AAGCTT & $27.0(6.0)$ & $13.8(0.7)$ & $22.9(6.8)$ & $13.5(2.2)$ \\
GGCC & $>50$ & $15.5(3.0)$ & $>50$ & $>50$
\end{tabular}

$K_{D}(\mu \mathrm{M})$ were measured in $20 \mathrm{mM}$ Tris-HCl buffer, $100 \mathrm{mM} \mathrm{NaCl}, \mathrm{pH} 7.5$ at $298 \mathrm{~K}$. [a] Hairpin oligonucleotide binding sites; [b] Best fit according to a 1:1 model obtained for three independent titrations. The estimated $K_{D}$ error is shown between brackets.

Saturation Transfer Difference (STD) NMR experiments also support the binding to the DNA. ${ }^{30}$ Thus, in the presence of ctDNA both enantiomers, $\mathbf{\Lambda} \mathbf{\Lambda}-$ and $\mathbf{\Delta} \mathbf{\Delta}-\mathbf{R} \mathbf{u}_{2}$, give rise to STD signals in the region of 7.0-8.5 ppm of their spectra (Figure $2 \mathrm{~d}, 2 \mathrm{e}$ ), as expected for molecules that reversibly bind to the macromolecular receptor in the fast exchange regime; these resonances are not found in the control STD spectrum in the absence of ctDNA (Figure 2b). Both the $\mathbf{\Lambda} \mathbf{\Lambda}$ - and $\mathbf{\Delta} \boldsymbol{\Delta}-\mathbf{R} \mathbf{u}_{2}$ enantiomers gave similar intensities in the STD experiments, in agreement with the similar values of their apparent binding affinities.

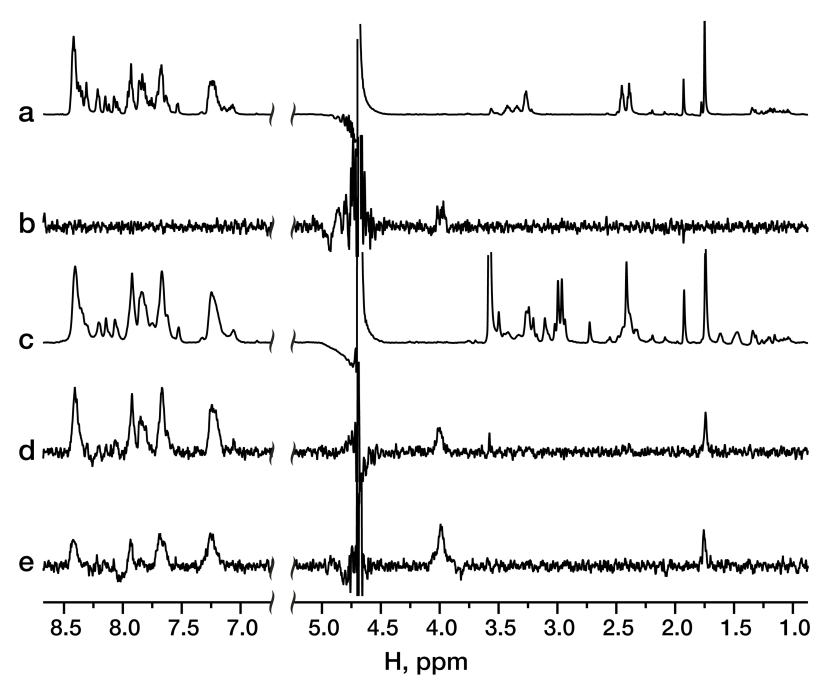

Figure 2. STD NMR spectra $\left(600 \mathrm{MHz}, \mathrm{H}_{2} \mathrm{O}, 25^{\circ} \mathrm{C}\right)$ of $\mathbf{\Lambda} \boldsymbol{\Lambda}$ - and $\boldsymbol{\Delta} \boldsymbol{\Delta}-\mathbf{R} \mathbf{u}_{2}$ with calfthymus DNA. (a) Reference (off-resonance) ${ }^{1} \mathrm{H}$ NMR spectrum of $150 \mu \mathrm{M} \boldsymbol{\Delta} \mathbf{\Delta}-\mathbf{R} \mathbf{u}_{2}$; (b) STD NMR of $150 \mu \mathrm{M} \Delta \mathbf{\Delta}-\mathbf{R} \mathbf{u}_{2}$; (c) Reference (off-resonance) ${ }^{1} \mathrm{H}$ NMR spectrum of a mixture of $150 \mu \mathrm{M}$ of $\boldsymbol{\Delta} \mathbf{\Delta}-\mathbf{R} \mathbf{u}_{2}$ with $150 \mu \mathrm{M}$ calf-thymus DNA; (d) STD NMR spectrum of the same sample in (c); (e) STD NMR of a mixture of $228 \mu \mathrm{M} \mathbf{\Lambda} \mathbf{\Lambda}-\mathbf{R u}_{2}$ and $250 \mu \mathrm{M}$ calf-thymus DNA. Saturation time was $2 \mathrm{~s}$ at frequencies $-40 \mathrm{ppm}$ (reference, off-resonance spectra) and $+4.0 \mathrm{ppm}$ (STD, on-resonance spectra).

Structural modification of the basic metallopeptide core: introduction of an octaarginine peptide tail. Given the relatively good DNA binding properties as well as the favorable luminescent emission displayed by the dinuclear ruthenium complexes, we were interested in studying their effect in living cells, but unfortunately these compounds were not internalized in Vero cells at concentrations of 5 or $25 \mu \mathrm{M}$ and during variable incubations times (30 min and $1 \mathrm{~h}$ ). Considering the effective cellular uptake induced by a number of cationic peptides, ${ }^{31}$ and oligoarginines in particular, ${ }^{32}$ we decided to take advantage of the flexibility afforded by the SPPS methodology to synthesize an octaarginine-diruthenium derivative $\left(\mathbf{R u}_{\mathbf{2}}-\mathbf{R}_{\mathbf{8}}\right)$. This oligocationic metallopeptide was obtained following the same basic synthetic procedure outlined earlier, with the difference that the two $\beta$ Ala-Bpy-coordinating building blocks were appended at the N-terminus of a previously synthesized octaarginine peptide (Scheme 2). Unfortunately, attempts to prepare $\mathbf{\Lambda} \mathbf{\Lambda}-\mathbf{R u}_{\mathbf{2}}-\mathbf{R}_{\mathbf{8}}$ or $\mathbf{\Delta} \mathbf{\Delta}-\mathbf{R} \mathbf{u}_{2}-\mathbf{R}_{\mathbf{8}}$ in the solid support were unsuccessful, because the high temperatures required for the coordination of the relatively unreactive chiral Hua and von Zelewsky's $\Lambda$-cis$\left[\mathrm{Ru}(\mathrm{Bpy})_{2}(\mathrm{py})_{2}\right]^{2+}$, or $\Delta$-cis- $\left[\mathrm{Ru}(\mathrm{Bpy})_{2}(\mathrm{py})_{2}\right]^{2+}$ reagents resulted in a complex mixture of peptide degradation products. Fortunately, the achiral $\left[\mathrm{Ru}(\mathrm{Bpy})_{2}(\mathrm{Cl})_{2}\right]$ precursor complex required lower reaction temperatures, and allowed the synthesis of the $\mathbf{R} \mathbf{u}_{\mathbf{2}}-\mathbf{R}_{\mathbf{8}}$ dinuclear complex as a diasteromeric mixture..$^{33}$

Fluorescence titrations showed that the resulting octaargininedinuclear $\mathrm{Ru}(\mathrm{II})$ metallopeptide $\mathbf{R} \mathbf{u}_{\mathbf{2}}-\mathbf{R}_{\mathbf{8}}$ displayed the same A/Trich sequence preference presented by the core $\mathbf{\Lambda} \Lambda$ - and $\Delta \mathbf{\Delta}-\mathbf{R} \mathbf{u}_{2}$ complexes. Moreover, the observed binding affinity for A/T-rich sequences was increased by this modification; probably because of the increased charge density of the oligocationic $\mathbf{R u}_{\mathbf{2}}-\mathbf{R}_{\mathbf{8}}$ complex, which presumably would favorably contribute to the electrostatic component of the interaction with the negatively-charged DNA phosphate backbone. As expected, $\mathbf{R} \mathbf{u}_{2}-\mathbf{R}_{\mathbf{8}}$ did not show any significant affinity for $\mathrm{G} / \mathrm{C}$-rich oligonucleotides. Moreover, the titration curve for the $\mathrm{G} / \mathrm{C}$-rich hairpin exhibited a rather complex 
multiphasic profile (see supporting information), consistent with the formation of multiple low-affinity and nonspecific complexes resulting from electrostatic interactions between the polyanionic DNA and the highly charged conjugate. ${ }^{34}$

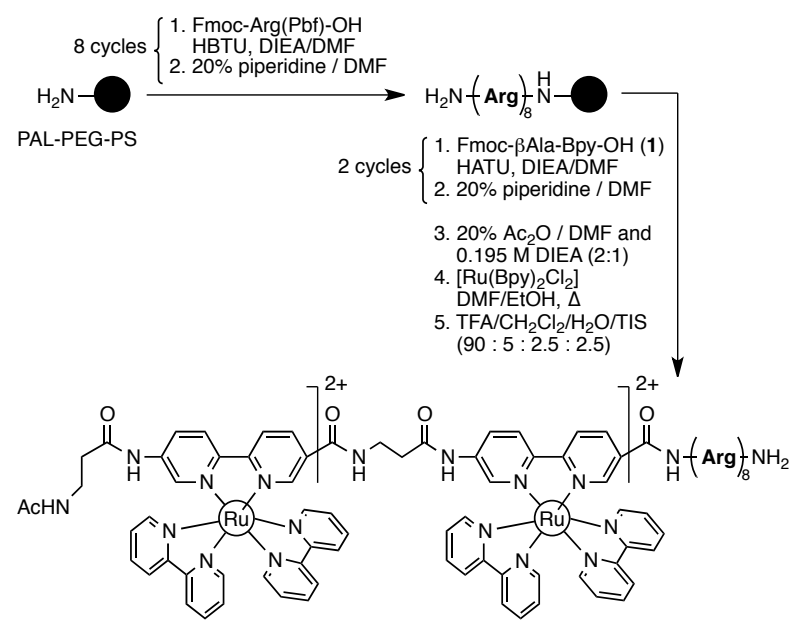

Scheme 2. Solid-Phase Peptide Synthesis (SPPS) of the octaarginine $\mathbf{R u}_{\mathbf{2}}-\mathbf{R}_{\mathbf{8}}$ dinuclear complex.

AFM studies of the DNA binding. The interaction of the Ru(II) compounds $\boldsymbol{\Delta} \mathbf{\Delta}-\mathbf{R} \mathbf{u}_{\mathbf{2}}$ and $\mathbf{R} \mathbf{u}_{2}-\mathbf{R}_{\mathbf{8}}$ with DNA was further investigated with Atomic-Force Microscopy (AFM). To carry out these experiments, relaxed plasmid pBR322 DNA was used, as it would allow us to directly observe any potential interactions with metal complexes. ${ }^{35}$ As evidenced in Figure 3a, the relaxed DNA molecules distributed over the mica surface mostly exhibit open (circular) structures with some crossing points (see light-red arrow in Figure 3a), which illustrate the initiation of supercoiling. The incubation of $\boldsymbol{\Delta \Delta} \mathbf{\Delta}-\mathbf{R u}_{2}$ with the relaxed plasmid for 24 hours clearly resulted in the alteration of the initial morphology of the DNA structure (Figure 4b); indeed, significantly more crossing points were observed and the formation of supercoiled forms was obvious (see light-blue arrows in Figure 3b). Moreover, large open forms such as those observed in Figure 3a were not present anymore. These features are indicative of strong interactions of $\boldsymbol{\Delta} \boldsymbol{\Delta}-\mathbf{R} \mathbf{u}_{2}$ with relaxed pBR322 DNA. Incubation with $\mathbf{R u}_{\mathbf{2}}-\mathbf{R}_{\mathbf{8}}$ revealed a higher affinity of the ruthenium compound (compared to $\Delta \mathbf{\Delta}-\mathbf{R} \mathbf{u}_{2}$ ) for DNA (Figure 3c); actually, the supercoiled forms of DNA were present in major proportion (in fact the supercoiled forms were visibly longer than those observed with $\mathbf{\Delta \Delta}-\mathbf{R} \mathbf{u}_{2}$; see light-green arrows in Figure 3c). The AFM results therefore corroborate the previous observations with spectroscopic methods and support the strong DNA binding observed with $\mathbf{R u}_{\mathbf{2}}-\mathbf{R}_{\mathbf{8}}$. Moreover, this significant effect of $\mathbf{R} \mathbf{u}_{2}-\mathbf{R}_{\mathbf{8}}$ on the DNA's degree of coiling may be compared to molecules, i.e. proteins that pack the DNA into chromosomes. Hence, such a compound may significantly hamper processes requiring the access of proteins to the DNA, for instance avoiding the formation of replication fork, and therefore exhibit good cytotoxicity. ${ }^{36}$

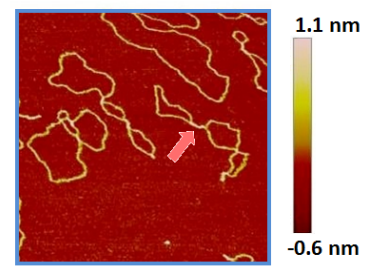

b)
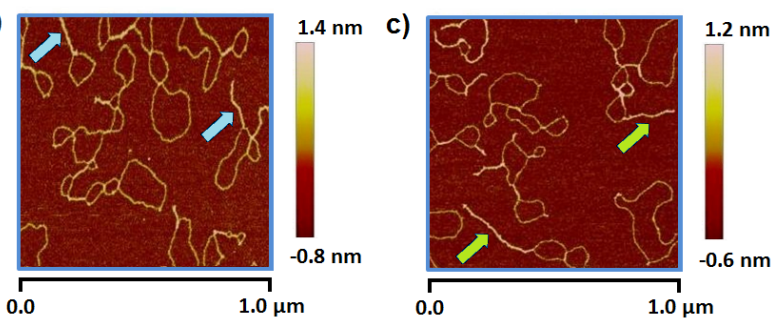

Figure 3. AFM images of (a) free relaxed pBR322 DNA $\left(19 \mu \mathrm{g} \mathrm{mL}^{-1}\right)$ and incubated at $37^{\circ} \mathrm{C}$ for 24 hours in HEPES with (b) complex $\mathbf{\Delta} \mathbf{\Delta}-\mathbf{R} \mathbf{u}_{2}(75 \mu \mathrm{g} \mathrm{mL}-1)$, or (c) complex $\mathbf{R u}_{2}-\mathbf{R}_{\mathbf{8}}\left(75 \mu \mathrm{g} \mathrm{mL}^{-1}\right)$

Cell internalization of the octaarginine metallopeptide and cytotoxicity assays. As expected, the introduction of the cationic oligoarginine endowed the $\mathbf{R} \mathbf{u}_{\mathbf{2}}-\mathbf{R}_{\mathbf{8}}$ conjugate with effective cellinternalization properties. Thus, incubation of a $25 \mu \mathrm{M}$ solution of $\mathbf{R u}_{2}-\mathbf{R}_{\mathbf{8}}$ for $30 \mathrm{~min}$ with Vero cells resulted in a clear and homogeneous emission in the red channel within the whole cell population (Figure 4, supporting information). At this concentration, the luminescence was observed in the form of a punctuated pattern in the cytoplasm, which could be related with the formation of endosomes involved in endocytosis, ${ }^{37}$ as well as diffuse emission from the cell nuclei (Figure 4).
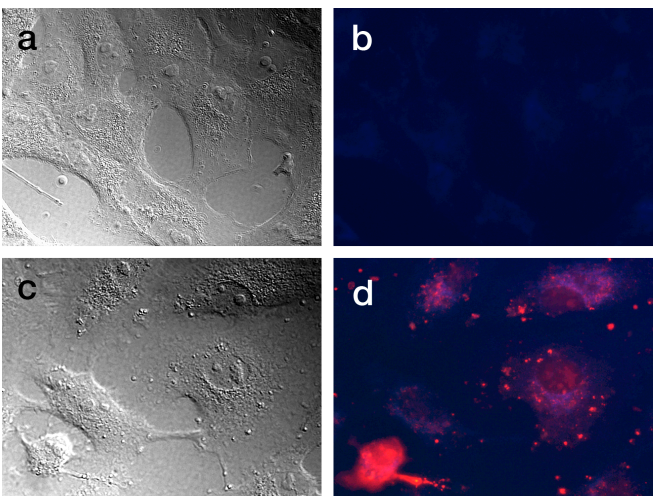

Figure 4. Monolayers of Vero cells grown in coverslips were incubated in DMEM without any additives, in the presence of $25 \mu \mathrm{M}$ of control compound $\mathbf{\Delta \Delta}-\mathbf{R} \mathbf{u}_{\mathbf{2}}$ (top row) or $\mathbf{R} \mathbf{u}_{2}-\mathbf{R}_{\mathbf{8}}$ (bottom row), for 30 minutes at $37^{\circ} \mathrm{C}$. The figure shows DIC images (left) and their correspondent fluorescence images (right). A highly emissive dead cell is seen at the bottom-left corner of panel d.

In addition with improved internalization, the $\mathbf{R u}_{\mathbf{2}}-\mathbf{R}_{\mathbf{8}}$ complex also displayed increased cytotoxic activity, in comparison with the unmodified $\mathbf{\Lambda} \mathbf{\Lambda}-$ and $\mathbf{\Delta} \boldsymbol{\Delta}-\mathbf{R} \mathbf{u}_{2}$ complexes. Thus, while a racemic mixture of the core $\mathbf{R} \mathbf{u}_{2}$ metallopeptides had an almost negligible inhibitory effect on the cellular proliferation of A2780cis ovarian carcinoma cells $\left(\mathrm{IC}_{50} \approx 286 \mu \mathrm{M}\right.$ ), the $\mathbf{R} \mathbf{u}_{\mathbf{2}}-\mathbf{R}_{\mathbf{8}}$ complex exhibited a much lower $\mathrm{IC}_{50}$ of $15 \mu \mathrm{M}$, comparable to that of cis-diamminedichloro-platinum(II) (cisplatin) under the same experimental conditions $\left(\mathrm{IC}_{50} \approx 7 \mu \mathrm{M}\right)$. Similar results were obtained for other cell lines, such as MCF-7 (breast cancer) or NCI-H460 (lung 
carcinoma), for which only the octaarginine-tagged $\mathbf{R} \mathbf{u}_{\mathbf{2}}-\mathbf{R}_{\mathbf{8}}$ metallopeptide had measurable inhibitory effects, which were in all cases comparable to those of cisplatin (supporting information).

\section{Conclusion}

In summary, we report a new class of DNA-binding homochiral dinuclear coordination compounds containing a bis-chelating peptide backbone, and the first examples of dinuclear ruthenium (II) metallopeptides. Detailed studies indicate that these compounds bind to DNA by insertion into the DNA with chiral discrimination between the $\mathbf{\Lambda} \mathbf{\Lambda}-$ and $\mathbf{\Delta} \boldsymbol{\Delta}-\mathbf{R} \mathbf{u}_{\mathbf{2}}$ isomers. Moreover, the synthetic versatility and flexibility of solid-phase peptide synthesis (SPPS) was exploited to modify the microstructure of the peptidic scaffold, thus allowing the straightforward modulation of the DNA-binding properties of the resulting complexes, as well as the introduction of additional functionalities and properties (i.e. introduction of the octaarginine tail for endowing the complexes with cell internalization properties). We believe that this innovative approach opens new perspectives for programming DNA binding metal complexes with novel and useful properties, and can be applied for the construction of novel polynuclear polypyridyl $\mathrm{Ru}(\mathrm{II})$ metallopeptides and related complexes derived from other metal ions.

\section{Experimental Section}

General Methods. All solvents were dry and of synthesis grade. Analytical RP-HPLC was performed with an Agilent 1100 series LC/MS with a Luna $\mathrm{C}_{18}(250 \times 4.60 \mathrm{~mm})$ analytical column. Peptides were purified using a Luna $\mathrm{C}_{18}(250 \times 10 \mathrm{~mm})$ semipreparative column. The standard gradient used both for analytical and semi-preparative HPLC was $5 \%$ to $50 \%$ over $30 \mathrm{~min}$ (water/acetonitrile, $0.1 \%$ TFA). The fractions containing the products were freeze-dried, and the identity of the products was confirmed by MALDI-TOF and Electrospray Ionization Mass Spectrometry, which was performed in an Agilent 1100 Series LC/MSD instrument in positive scan mode. Luminescence titration experiments were made with a Jobin-Yvon Fluoromax-3. All measurements were made at $20{ }^{\circ} \mathrm{C}$ with the following settings: excitation at $488 \mathrm{~nm}$; excitation slit width $3.0 \mathrm{~nm}$, emission slit with $6.0 \mathrm{~nm}$; increment $1.0 \mathrm{~nm}$; integration time $1 \mathrm{~s}$. The emission spectra were recorded from 515 to $780 \mathrm{~nm}$. Circular dichroism measurements were made with a Jasco J-715 coupled to a thermostated water bath at 20 ${ }^{\circ} \mathrm{C}$.

Solid phase synthesis of peptidic ligands. C-terminal amide peptides were synthesized following standard SPPS protocols on a $0.05 \mathrm{mmol}$ scale using a $0.20 \mathrm{mmol} / \mathrm{g}$ FmocPAL-PEG-PS or $0.45 \mathrm{mmol} / \mathrm{g}$ Fmoc-Rink-amide resins. Glycine and arginine were coupled, in 10-fold excess (versus mmol of resin load), using HBTU as activating agent. The synthetic Fmoc- $\beta$ Ala-5-Bipy-OH amino acid (1) was coupled in 5-fold excess using HATU as activating agent. Couplings were conducted for $1 \mathrm{~h}$. Deprotection of the temporal Fmoc protecting group was performed with 20\% piperidine in DMF for 15 min. Test cleavages were performed at a $5 \mathrm{mg}$ scale for $2 \mathrm{~h}$ with $50 \mu \mathrm{L} \mathrm{CH}_{2} \mathrm{Cl}_{2}, 25 \mu \mathrm{L}$ $\mathrm{H}_{2} \mathrm{O}, 25 \mu \mathrm{L}$ TIS, triisopropylsilane, and $900 \mathrm{TFA} \mu \mathrm{L}(\approx 1 \mathrm{~mL}$ of cocktail for $100 \mathrm{mg}$ of resin).

Synthesis of homochiral Ru(II) metallopeptides. Once the peptide ligands were synthesized, the resin was suspended in $6 \mathrm{~mL}$ of DMF in the dark for $15 \mathrm{~min}$. The selected chiral precursor $\Delta-$ or $\Lambda-\left[\mathrm{Ru}(\mathrm{bpy})_{2}(\mathrm{Py})_{2}\right] \mathrm{DBT}(\mathrm{DBT}=$ dibenzoyl tartrate) was added $(0.15 \mathrm{mmol}, 111 \mathrm{mg})$, and the resulting mixture was stirred under argon for four days at $110{ }^{\circ} \mathrm{C}$. The resin was filtered, washed with DMF and $\mathrm{CH}_{2} \mathrm{Cl}_{2}$ and dried. The metallopeptide was cleaved with the TFA cocktail; the resin was filtered and the supernatant was concentrated and dissolved in water. Addition of $\mathrm{NH}_{4} \mathrm{PF}_{6}$ yielded a red precipitate, which was purified by semi-preparative HPLC to give the desired product $\boldsymbol{\Delta} \boldsymbol{\Delta}-\mathbf{R u}_{2}$ : MALDI-TOF calcd for $\mathrm{C}_{70} \mathrm{H}_{61} \mathrm{~N}_{17} \mathrm{O}_{5} \mathrm{Ru}_{2}, 1423.3$; found, 1420.4. ESI-MS calcd for $\left[\mathrm{M}+2 \mathrm{CF}_{3} \mathrm{COO}^{-}\right]^{2+}, 824.5$; found, 823.3. $\mathbf{\Lambda} \mathbf{\Lambda}-\mathbf{R} \mathbf{u}_{2}$ : MALDI-TOF calcd for $\mathrm{C}_{70} \mathrm{H}_{61} \mathrm{~N}_{17} \mathrm{O}_{5} \mathrm{Ru}_{2}, 1423.3$; found, 1420.4. ESI-MS calcd for $\left[\mathrm{M}+2 \mathrm{CF}_{3} \mathrm{COO}^{-}\right]^{2+}, 824.5$ found, 823.3. $\boldsymbol{\Delta} \boldsymbol{\Delta}-\mathbf{R} \mathbf{R u}_{2} \mathbf{G l y}$ : MALDI-TOF calcd for $\mathrm{C}_{72} \mathrm{H}_{64} \mathrm{~N}_{18} \mathrm{O}_{6} \mathrm{Ru}_{2}, 1480.3$; found, 1480.3. ESI-MS calcd for $\left[\mathrm{M}+2 \mathrm{CF}_{3} \mathrm{COO}^{-}\right]^{2+}, 853.1$; found, 852.8. $\mathbf{\Lambda} \mathbf{\Lambda}-\mathbf{R} \mathbf{u}_{2} \mathbf{G l y}$ : MALDI-TOF calcd for $\mathrm{C}_{72} \mathrm{H}_{64} \mathrm{~N}_{18} \mathrm{O}_{6} \mathrm{Ru}_{2}, 1480.33$; found, 1480.3. ESI-MS calcd for [M $\left.+2 \mathrm{CF}_{3} \mathrm{COO}^{-}\right]^{2+}, 853.1$; found, 852.8 .

Synthesis of racemic Ru(II) metallopeptides. Once the peptide ligands were synthesized, the resin was suspended in $6 \mathrm{~mL}$ of $1: 1 \mathrm{EtOH} / \mathrm{DMF}$ in the dark for $15 \mathrm{~min}$ The neutral precursor complex $\mathrm{Ru}(\mathrm{Bpy})_{2} \mathrm{Cl}_{2}$ was added $(0.15 \mathrm{mmol} ; 71 \mathrm{mg})$, and the resulting mixture was stirred, under argon atmosphere, during 3 days at $70{ }^{\circ} \mathrm{C}$. The resin was then filtered, washed extensively with $\mathrm{DMF}$ and $\mathrm{CH}_{2} \mathrm{Cl}_{2}$ and dried under vacuum. The complex was cleaved from the solid support by treating the resin with the standard TFA cocktail. The TFA phase was concentrated by bubbling nitrogen, diluted in water. Addition of $\mathrm{NH}_{4} \mathrm{PF}_{6}$ to the aqueous solution yields a red precipitate, which was dissolved in $\mathrm{H}_{2} \mathrm{O} / \mathrm{CH}_{3} \mathrm{CN}$ (3:1) and purified by semi-preparative reverse-phase HPLC to give the desired product. $\mathbf{R u}_{2}-\mathbf{R}_{\mathbf{8}}$ : MALDI-TOF calcd for $\mathrm{C}_{118} \mathrm{H}_{155} \mathrm{~N}_{49} \mathrm{O}_{13} \mathrm{Ru}_{2}, 2670.1$; found $=2669.9$ ESI-MS calcd for $\left[\mathrm{M}+5 \mathrm{CF}_{3} \mathrm{COO}^{-}+4 \mathrm{H}^{+}\right]^{3+}, 1079.7$; found $=1081.2$. ESI-MS calcd for $\left[\mathrm{M}+6 \mathrm{CF}_{3} \mathrm{COO}^{-}+5 \mathrm{H}^{+}\right]^{3+}, 1117.7$; found $=1117.3$, calcd for $[\mathrm{M}+7$ $\left.\mathrm{CF}_{3} \mathrm{COO}^{-}+6 \mathrm{H}^{+}\right]^{3+}$, 1155.7; found, 1155.8. $\mathbf{R u}_{2}$ : MALDI-TOF calcd for $\mathrm{C}_{70} \mathrm{H}_{61} \mathrm{~N}_{17} \mathrm{O}_{5} \mathrm{Ru}_{2}, 1423.31$; found, 1420.4. ESI-MS calcd for $\left[\mathrm{M}+2 \mathrm{CF}_{3} \mathrm{COO}^{-}\right]^{2+}, 824.5$; found $=823.3$.

Saturation Transfer Difference (STD) NMR studies. NMR samples were prepared in $500 \mu \mathrm{L}$ of aqueous buffer containing $10 \%(v / v) \mathrm{D}_{2} \mathrm{O}, 100 \mathrm{mM} \mathrm{NaCl}$ and $10 \mathrm{mM}$ phosphate buffer at $\mathrm{pH} 7.5$ (not corrected for $\mathrm{D}_{2} \mathrm{O}$ ). All STD NMR experiments were performed on a Bruker Avance 600 spectrometer (Billerica, MA, USA) operating at $600.13 \mathrm{MHz}$ for ${ }^{1} \mathrm{H}$, equipped with a $5 \mathrm{~mm}$ inverse triple resonance probe with $Z$-only gradients. Spectra were processed with TopSpin and MestreNova. A pseudo-2D version of the STD NMR pulse sequence was used for the interleaved acquisition of on- and off-resonance spectra. Selective saturation of the DNA was performed with a train of 40 Gauss-shaped pulses of $50 \mathrm{~ms}$ length each, separated by a $1 \mathrm{~ms}$ delay, leading to a total saturation time of $2.04 \mathrm{~s}$. The on-resonance irradiation of the DNA was set at a chemical shift of +1.0 and $+4.0 \mathrm{ppm}$. Off-resonance irradiation was applied at $-40.0 \mathrm{ppm}$, where no DNA signals were present. Solvent suppression was achieved with the double pulsed-field gradient spin-echo (DPFGSE) step. ${ }^{38}$ The STD NMR spectra were multiplied by an exponential line-broadening function of $3.0 \mathrm{~Hz}$ prior to Fourier transformation. Saturation transfer was observed in spectra irradiated either at 1.0 or 4.0 $\mathrm{ppm}$. Peak intensities were larger when saturating at $4.0 \mathrm{ppm}$ (discussed in the text). Appropriate blank experiments, in the absence of ctDNA, were performed to test the lack of direct saturation to the ligand protons.

Atomic Force Microscopy (AFM) studies. The AFM images were obtained with a Multimode 8 AFM with electronic Nanoscope V scanning probe microscope from Bruker AXS, using the PEAK FORCE tapping mode. Commercial Si-tip on Nitride lever cantilevers (SNL, Bruker) with force constant of $0.4 \mathrm{~N} / \mathrm{m}$ were used. The samples were deposited on mica disks (PELCO Mica Discs, $9.9 \mathrm{~mm}$ diameter; Ted Pella, Inc.), and dried before visualization. Solutions of the metal complexes and the buffer were prepared just prior to use, and filtered through $0.2 \mathrm{~nm}$ FP030/3 filters (Scheicher and Schuell, Germany). The samples were prepared in HEPES with relaxed plasmid pBR322 DNA $(19 \mu \mathrm{g} / \mu \mathrm{L})$ and the corresponding metallopeptide $\left(75 \times 10^{-3} \mu \mathrm{g} / \mathrm{mL}\right)$. All samples were incubated for 24 hours at $37^{\circ} \mathrm{C}$ before the AFM studies.

Cell internalization studies. Semi-confluent monolayers of Vero cells were grown on glass coverslips in DMEM (Dulbecco's modified Eagle Medium) containing 10\% of FBA (Fetal bovine serum). For the assays, the cells were incubated in DMEM containing no FBS or antibiotics, with control compound $\mathbf{R} \mathbf{u}_{2}(25 \mu \mathrm{M})$ or $\mathbf{R} \mathbf{u}_{2}-\mathbf{R}_{\mathbf{8}}(25$ $\mu \mathrm{M}$ and $5 \mu \mathrm{M})$, during 60 or 30 minutes at $37{ }^{\circ} \mathrm{C}$ in a $5 \% \mathrm{CO}_{2}$ humidified atmosphere. Then, the cells were gently washed 5 times with PBS (Phosphate Buffered Saline), and observed under the fluorescence microscope in DMEM without fixation.

\section{Acknowledgements}

We thank the support given by the Spanish grants SAF2010-20822-C02, CTQ201231341, CTQ2009-14431, CTQ2011-27929-C02-01, SAF2007-61015, and the Xunta de Galicia INCITE09 209 084PR, GRC2010/12, PGIDIT08CSA-047209PR. Support of COST Action CM1105 is kindly acknowledged. I. S. thanks the Fundación José OteroCarmela Martinez for her PhD fellowship. M. I. S. and G. R. thank the Spanish Ministry of Science and Technology, and the European Nanotechnology Laboratory (ENL), respectively, for their $\mathrm{PhD}$ fellowships.

1 a) D. R. Boer, A. Canals, M. Coll, J. Chem. Soc., Dalton Trans. 2009, 3, 399414; b) R. Palchaudhuri, P. J. Hergenrother, Curr. Opin. Biotechnol. 2007, 18 , 497-503; c) S. M. Nelson, L. R. Ferguson, W. A. Denny, Mutat. Res. 2007, 623, 24-40; d) W. C. Tse, D. L. Boger, Chem. Biol. 2004, 11, 1607-1617; e) S. Neidle, Nat. Prod. Rep. 2001, 18, 291-309; f) P. N. Dervan, Science 1986, 232, 464-471. For a recent review on designed DNA binding agents: E. Pazos, J. Mosquera, M. E. Vázquez, J. L. Mascareñas, ChemBioChem 2011, 12, 19581973.

2 a) A. C. Komor, J. K. Barton, Chem. Commun. 2013, 49, 3617-3630; b) D. A Richards, A. Rodger, Chem. Soc. Rev. 2007, 36, 471-483; c) B. M. Zeglis, V. C. Pierre, J. K. Barton, Chem. Commun. 2007, 4565-4579; d) K. L. Haas, K. Franz Chem. Rev. 2009, 109, 4921-4960; e) P. C. A. Bruijnincx, P. J. Sadler, Curr. Opin. Chem. Biol. 2008, 12, 197-206; f) A. Pyle, J. K. Barton, Bioinorganic Chemistry, Eds.: Lippard, S. J., John Wiley \& Sons, Inc., New York, 1990, p. 413.

3 a) J. Reedijk, Eur. J. Inorg. Chem. 2009, 1303-1312; b) L. Kelland, Nature Rev Cancer 2007, 7, 573-584; b) E. R. Jamieson, S. J. Lippard, Chem. Rev. 1999, 99, 2467-2498. 

4884-4892.

a) C. A. Puckett, J. K. Barton, J. Am. Chem. Soc. 2009, 131, 8738-8739; b) J. Brunner, J. K. Barton, Biochemistry 2006, 45, 12295-12302.

6 M. R: Gill, J. García-Lara, S. J. Foster, C. Smythe, G. Battaglia, J. A. Thomas, Nature Chem. 2009, 1, 662-667.

7 a) C. Hiort, P. Lincoln, B. Nordén, J. Am. Chem. Soc. 1993, 115, 3448-3454; b) M. Eriksson, M. Leijon, C. Hiort, B. Nordén, A. Graeslund, J. Am. Chem. Soc. 1992, 114, 4933-4934; c) A. Reymer, B. Nordén, Chem. Commun. 2012, 48 4941-4943.

8 a) C. R. Brodie, J. R. Aldrich-Wright, Eur. J. Inorg. Chem. 2007, 2007, 47814793; b) C. Metcalfe, J. A. Thomas, Chem. Soc. Rev. 2003, 32, 215-224.

9 a) S. Sun, F. Li, F. Liu, X. Yang, J. Fan, F. Song, L. Sun, X. Peng, Dalton Trans 2012, 41, 12434-12438; b) V. Gonzalez, T. Wilson, I. Kurihara, A. Imai, J. A Thomas, J. Otsuki, Chem. Commun. 2008, 1868-1870; c) C. B. Spillane, J. A. Smith, J. L. Morgan, F. R. Keene, J. Biol. Inorg. Chem. 2007, 12, 819-824; d) F: Pierard, A. K.-D. Mesmaeker, Inorg. Chem. Commun. 2006, 9, 111-126.

10 a) M. P. Fitzsimons, J. K. Barton, J. Am. Chem. Soc. 1997, 119, 3379-3380; b) L. Cardo, V. Sadovnikova, S. Phongtongpasuk, N. J. Hodges, M. J. Hannon, J. Chem. Commun. 2011, 47, 6575-6577.

11 a) C. R. Brodie, J. R. Aldrich-Wright, Eur. J. Inorg. Chem. 2007, 2007, 47814793; b) T. M. Pappenfus, K. R. Mann, Inorg. Chem. 2001, 40, 6301-6307; c) Y Nakabayashi, H. Inada, Y. Minoura, N. Iwamoto, O. Yamauchi, Inorg. Chim. Acta 2009, 362, 869-877.

12 a) U. Mcdonnell, M. R. Hicks, M. J. Hannon, A. Rodger, J. Inorg. Biochem. 2008, 102, 2052-2059; b) P. Nordell, F. Westerlund, L. M. Wilhelmsson, B Nordén, P. Lincoln, Angew. Chem. Int. Ed. 2007, 46, 2203-2206; c) O. Gijte, A.-D. Mesmaeker, J. Chem. Soc., Dalton Trans. 1999, 951-956; d) F. O'Reilly, J. Kelly, New. J. Chem. 1998, 22, 215-217; e) A.-D. Mesmaeker, Chem. Commun. 1996, 1013-1014.

13 J. A. Smith, J. G. Collins, F. R. Keene, in Metal complex-DNA interactions (Eds.: N. Hadjiliadis and E. Sletten), Wiley-Blackwell, Chichester, UK, 2009 , pp. 319-346.

14 a) O. Vázquez, M. I. Sánchez, J. Martínez-Costas, J. L. Mascareñas, M. E Vázquez, Chem. Commun. 2010, 46, 5518-5520; b) O. Vázquez, M. I. Sánchez, J. Martínez-Costas, M. E. Vázquez, J. L. Mascareñas, Org. Lett. 2010, 12, 216 219; c) A. M. Caamaño, M. E. Vázquez, J. Martínez-Costas, L. Castedo, J. L. Mascareñas, Angew. Chem. Int. Ed. 2000, 39, 3104-3107; d) M. E. Vázquez, A. M. Caamaño, J. Martínez-Costas, L. Castedo, J. L. Mascareñas, Angew. Chem. Int. Ed. 2001, 40, 4723-4725.

15 G. Rama, A. Ardá, J.-D. Maréchal, I. Gamba, H. Ishida, J. Jiménez-Barbero, M. E. Vazquez, M. Vázquez López, Chem. Eur. J. 2012, 18, 7030-7035.

16 B. Happ, A. Winter, M. D. Hager, U. S. Schubert, Chem. Soc. Rev. 2012, 41, $2222-2225$.

17 a) A. Torrado, B. Imperiali, J. Org. Chem. 1996, 61, 8940-8948; b) M. Kyakuno, S. Oishi, H. Ishida, Inorg. Chem. 2006, 45, 3756-3765; c) M. Kyakuno, S. Oishi, H. Ishida, Chem. Lett. 2005, 34, 1554-1555; d) H. Ishida, M. Kyakuno, S. Oishi, Biopolymers 2004, 76, 69-82; e) M. Y. Ogawa, A. Gretchikhine, S. Soni, S. Davis, Inorg. Chem. 1995, 34, 6423-6424.

18 N. Sewald, H.-D. Jakubke, in Peptides: Chemistry and Biology, Wiley-VCH, Weinheim, 2002, pp. 135.

19 a) A. Papakyriakou, G. Malandrinos, A. Garoufis, J. Inorg. Biochem. 2006, 100, 1842-1848; b) X. Hua, A. von Zelewsky, Inorg. Chem. 1995, 34, 5791-5797; c) X. Hua, A. von Zelewsky, Inorg. Chem. 1991, 30, 3796-3798; d) M. Brissard, O. Convert, M. Gruselle, C. Guyard-Duhayon, R. Thouvenot, Inorg. Chem. 2003, $42,1378-1385$.

20 a) M. R. Ghadiri, C. Soares, C. Choi, J. Am. Chem. Soc. 1992, 114, 4000-4002; b) H. Ishida, Y. Maruyama, M. Kyakuno, Y. Kodera, T. Maeda, S. Oishi,
ChemBioChem 2006, 7, 1567-1570; c) H. Ishida, M. Kyakuno, S. Oishi, Biopolymers 2004, 76, 69-82.

21 a) K. Karidi, A. Garoufis, N. Hadjiliadis, J. Reedijk, J. Chem. Soc., Dalton Trans. 2005, 728-734; b) K. Triantafillidi, K. Karidi, J. Malina, A. Garoufis, Dalton Trans. 2009, 6403-6415.

22 The nearest precedents are dinuclear complexes attached to short peptide chains: a) M. P. Fitzsimons, J. K. Barton, J. Am. Chem. Soc. 1997, 119, 3379-3380; b) L. Cardo, V. Sadovnikova, S. Phongtongpasuk, N. J. Hodges, M. J. Hannon, Chem. Commun. 2011, 47, 6575-6577.

23 a) Y.-M. Chen, Y.-J. Liu, Q. Li, K.-Z. Wang, J. Inorg. Biochem. 2009, 103, 1395-1404; b) M.-J. Han, L.-H. Gao, Y.-Y. Lü, K.-Z. Wang, J. Phys. Chem. B 2006, 110, 2364-2371.

24 a) C. V. Kumar, J. K. Barton, N. J. Turro, J. Am. Chem. Soc. 1985, 107, 55185523 ; b) W. J. Mei, J. Liu, K. C. Zheng, L. J. Lin, H. Chao, A. X. Li, F. C. Yun, L. N. Ji, Dalton Trans. 2003, 1352-1359.

25 a) P. Lincoln, B. Nordén, J. Phys. Chem. B 1998, 102, 9583-9594; b) H. Görner, A. B. Tossi, C. Stradowski, D. Schulte-Frohlinde, J. Photochem. Photobiol. B, Biol. 1988, 2, 67-89.

26 a) M. R. Gill, H. Derrat, C. G. W. Smythe, G. Battaglia, J. A. Thomas, ChemBioChem 2011, 12, 877-880; b) F. Westerlund, P. Lincoln, Biophys. Chem 2007, 129, 11-17; c) M.-J. Han, L.-H. Gao, Y.-Y. Lü, K.-Z. Wang, J. Phys. Chem. B 2006, 110, 2364-2371; d) S. Arounaguiri, B. Maiya, Inorg. Chem. 1999, 38, 842-843.

27 a) Y. Nakabayashi, H. Inada, Y. Minoura, N. Iwamoto, O. Yamauchi, Inorg Chim. Acta 2009, 362, 869-877; b) N. Chitrapriya, Y. J. Jang, S. K. Kim, H. J. Lee, Inorg. Biochem. 2011, 105, 1569-1575.

28 a) E. Corral, A. C. G. Hotze, H. den Dulk, A. Leczkowska, A. Rodger, M. J. Hannon, J. Reedijk, J. Biol. Inorg. Chem. 2009, 14, 439-448; b) K. Karidi, J. Reedijk, N. Hadjiliadis, A. Garoufis, J. Inorg. Biochem. 2007, 101, 1483-1491.

29 S. Komeda, T. Moulaei, M. Chikuma, A. Odani, R. Kipping, N. P. Farrell, L. D. Williams, Nucleic Acids Res. 2011, 39, 325-336.

30 a) B. Mayer, B. Meyer, Angew. Chem. Int. Ed. 1999, 38, 1784-1788; b) B. Meyer, T. Peters, Angew. Chem. Int. Ed. 2003, 42, 864-890.

31 a) K. Melikov, L. V. Chernomordik, Cell Mol. Life Sci. 2005, 62, 2739-2749; b) C. N. Carrigan, B. Imperiali, Anal. Biochem. 2005, 341, 290-298; c) S. Futaki, Adv. Drug Deliv. Rev. 2005, 57, 547-558.

32 a) C.-H. Tung, R. Weissleder, Adv. Drug Deliv. Rev. 2003, 55, 281-294; b) E. A. Goun, T. H. Pillow, L. R. Jones, J. B. Rothbard, P. A. Wender, ChemBioChem 2006, 7, 1497-1515.

33 a) U. Mcdonnell, J. M. C. A. Kerchoffs, R. P. M. Castineiras, M. R. Hicks, A. C. G. Hotze, M. J. Hannon, A. Rodger, Dalton Trans. 2008, 667-675; b) A. C. G. Hotze, N. J. Hodges, R. E. Hayden, C. Sanchez-Cano, C. Paines, N. Male, M.-K Tse, C. M. Bunce, J. K. Chipman, M. J. Hannon, Chem. Biol. 2008, 15, 12581267; G. I. Pascu, A. C. G. Hotze, C. Sanchez-Cano, B. M. Kariuki, M. J. Hannon, Angew. Chem. Int. Ed. 2007, 46, 4374-4378.

34 J. A. Holbrook, O. V. Tsodikov, R. M. Saecker, M. T. Record Jr, J Mol. Biol. 2001, 310, 379-401.

35 G. B. Onoa, V. Moreno, Int. J. Pharm. 2002, 245, 55-65.

36 a) M. J. Hannon, V. Moreno, M. J. Prieto, E. Moldrheim, E. Sletten, I. Meistermann, C. J. Isaac, K. J. Sanders, A. Rodger, Angew. Chem. Int. Ed. 2001, 40, 879-884; b) L. Childs, J. Malina, B. Rolfsnes, M. Pascu, M. Prieto, M. Broome, P. Rodger, E. M. Sletten, V. Moreno, A. Rodger, M. J. Hannon, Chem. Eur. J. 2006, 12, 4919-4927.

37 Endocytosis is one of the proposed mechanisms for the internalization of oligoarginine peptides into cells: C. A. Puckett, J. K. Barton, J. Am. Chem. Soc. 2009, 131, 8738-8739.

38 T. L. Hwang, A. J. Shaka, J. Magn. Reson. A. 1995, 112, 275-279.

Received: ((will be filled in by the editorial staff))

Revised: ((will be filled in by the editorial staff))

Published online: ((will be filled in by the editorial staff)) 


\section{Custom-fit ruthenium(II) metallopeptides: A new twist to DNA binding with coordination compounds}

Ilaria Gamba, Iria Salvadó, Gustavo Rama, Miriam Bertazzon, Mateo I. Sánchez, Víctor M. Sánchez-Pedregal, José MartínezCostas, Rosa F. Brissos, Patrick Gamez, José L. Mascareñas, Miguel Vázquez López* and M. Eugenio Vázquez*...... Page Page

Custom-fit ruthenium(II) metallopeptides: A new twist to DNA binding with coordination compounds

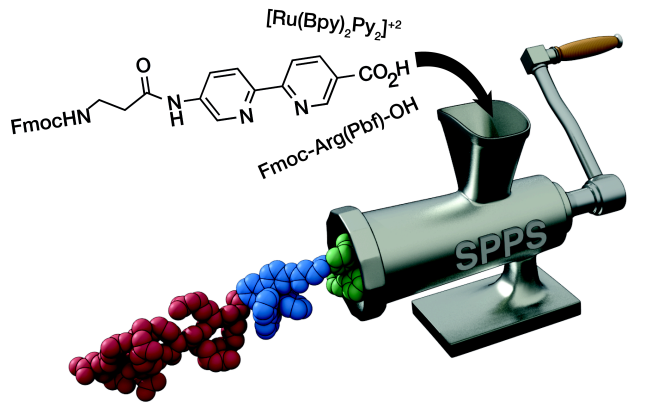

A new bipyridine building block has been used for the solid-phase synthesis of dinuclear DNA-binding ruthenium(II) metallopeptides which bind to the DNA. The potential of the solid-phase peptide synthesis is demonstrated by the straightforward synthesis of an octaarginine derivative that shows effective cellular internalization and cytotoxicity linked with strong DNA interaction. 